\title{
Mineral Resources of the Roberts
}

\section{Wilderness Study Area, Eureka}

\section{County, Nevada}

\section{U.S. GEOLOGICAL SURVEY BULLETIN 1731-K}

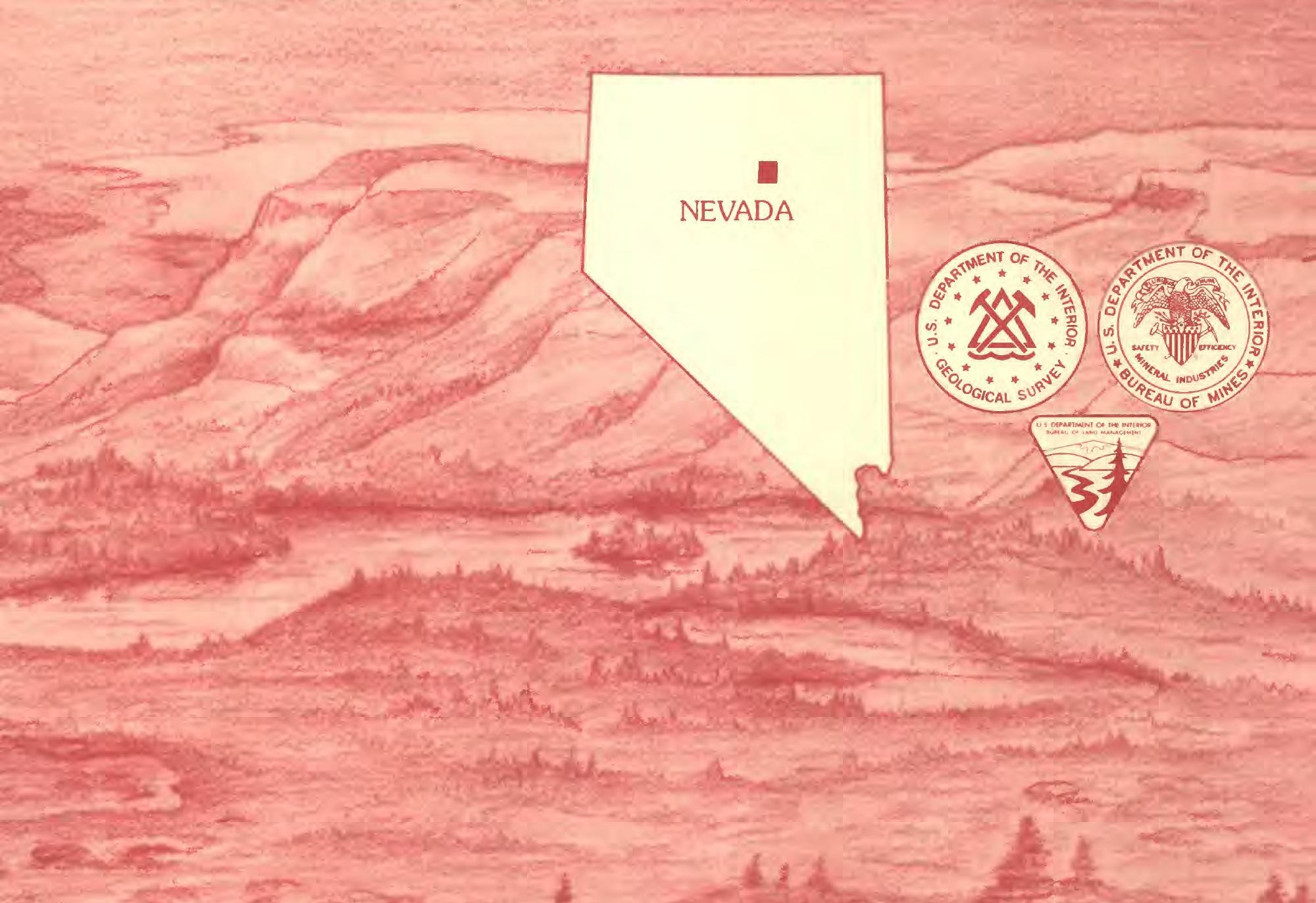



Chapter K

\section{Mineral Resources of the Roberts Wilderness Study Area, Eureka County, Nevada}

By EDWIN H. McKEE, HARLAN N. BARTON, and DAVID A. PONCE U.S. Geological Survey

DAVID A. BENJAMIN and FREDERICK L. JOHNSON U.S. Bureau of Mines

U.S. GEOLOGICAL SURVEY BULLETIN 1731-K

MINERAL RESOURCES OF WILDERNESS STUDY AREAS: CENTRAL NEVADA 


\title{
DEPARTMENT OF THE INTERIOR
}

DONALD PAUL HODEL, Secretary

\author{
U.S. GEOLOGICAL SURVEY
}

Dallas L. Peck, Director

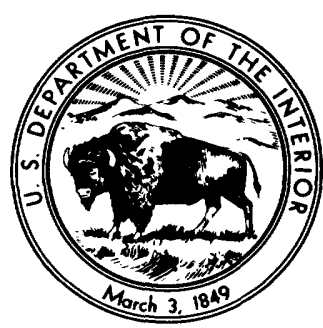

UNITED STATES GOVERNMENT PRINTING OFFICE : 1986

For sale by the

Books and Open-File Reports Section

U.S. Geological Survey

Federal Center, Box 25425

Denver, CO 80225

Library of Congress Cataloging-in-Publication Data

Mineral Resources of the Roberts Wilderness Study Area, Eureka County, Nevada.

U.S. Geological Survey Bulletin 1731-K

Bibliography: p. K9

Supt. of Docs. No.: I 19.3:1731-K

1. Mines and mineral resources-Nevada-Roberts Mountains Wilderness. 2. Geology-Nevada-Roberts Mountains Wilderness. 3. Roberts Mountains Wilderness (Nev.) I. McKee, Edwin H. II. Series.

QE75.B9 No. 1731-K

$557.3 \mathrm{~s}$

[TN24.N3]

[553'.09793'32]

$86-600141$ 
STUDIES RELATED TO WILDERNESS

\section{Bureau of Land Management Wilderness Study Area}

The Federal Land Policy and Management Act (Public Law 94-579, October 21, 1976) requires the U.S. Geological Survey and the U.S. Bureau of Mines to conduct mineral surveys on certain areas to determine their mineral values, if any, that may be present. Results must be made available to the public and be submitted to the President and the Congress. This report presents the results of a mineral survey of the Roberts Wilderness Study Area (NV-060-541), Eureka County, Nevada. 



\section{CONTENTS}

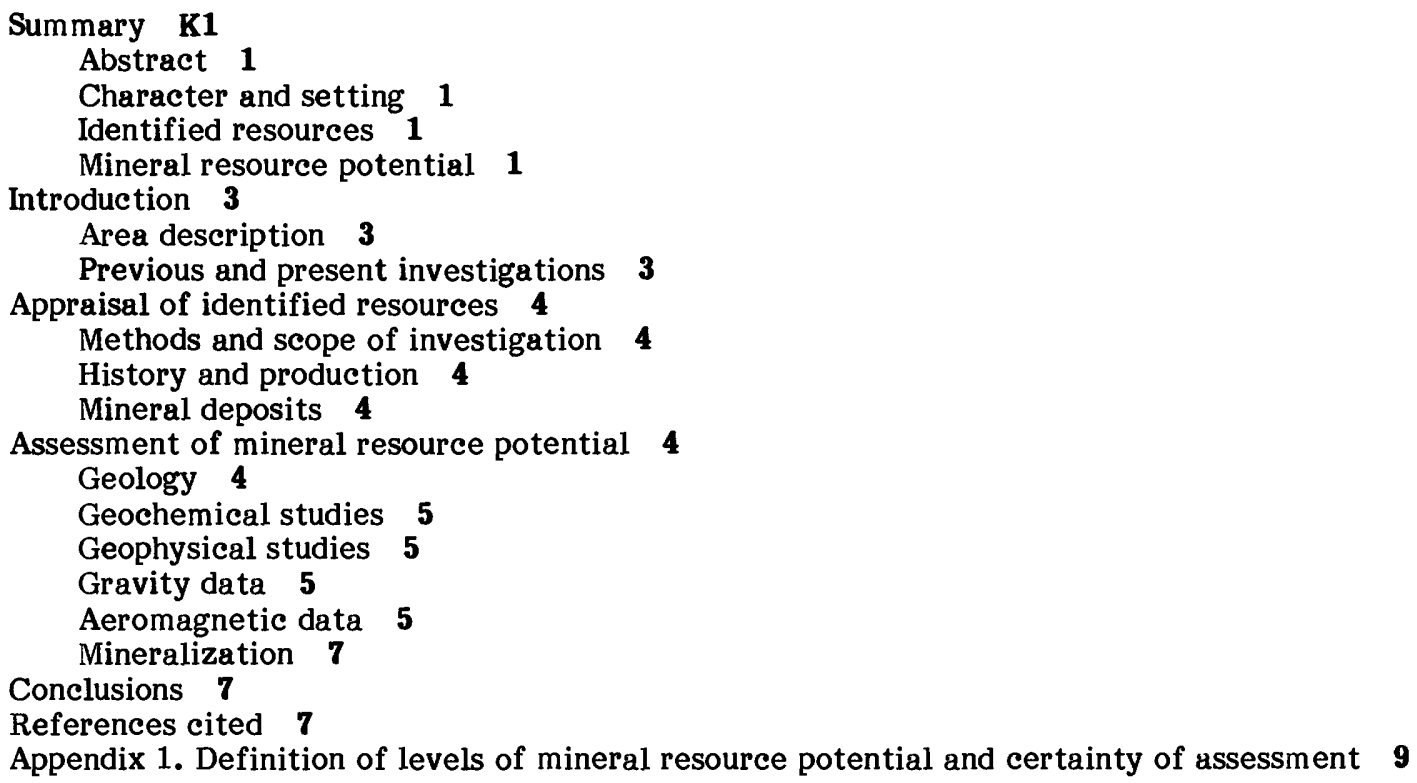

Appendix 1. Definition of levels of mineral resource potential and certainty of assessment 9

\section{PLATE}

In Pocket

1. Mineral resource potential map of the Roberts Wilderness Study Area, Eureka County, Nevada.

\section{FIGURES}

1. Index map showing location of the Roberts Wilderness Study Area, Eureka County, Nevada K2

2. Map showing mineral resource potential of the Roberts Wilderness Study Area 6

3. Major elements of mineral resource potential/certainty classification $\mathbf{9}$

\section{TABLE}

1. Sumple description and analyses of chip samples from Kelly mine $\mathbf{K} 10$ 



\title{
Mineral Resources of the Roberts Wilderness Study Area, Eureka County, Nevada
}

\author{
By Edwin H. McKee, Harlan N. Barton, and David A. Ponce \\ U.S. Geological Survey
}

David A. Benjamin and Frederick L. Johnson

U.S. Bureau of Mines

\section{SUMMARY}

\begin{abstract}
The Roberts Wilderness Study Area (NV-060-541) encompasses 15,090 acres and includes Roberts Creek Mountain, Cooper Peak, and Western Peak, three of the highest peaks in the Roberts Mountains, Eureka County, Nev. Field work for this report was carried out between May and August 1984 and augmented geologic mapping and other geologic studies that have continued for more than 20 years. Stream-sediment samples from the Kelley Creek drainage contain anomalous amounts of silver, lead, and zinc; the area including this drainage has low mineral resource potential for these metals in hydrothermal veins that follow faults and shear zones in carbonate host rock. The abandoned Kelley mine produced 397 tons of silver, lead, and zinc ore prior to 1940 . Some rock samples from outcrops along the east edge of the study area contain anomalous amounts of gold and silver, as well as a suite of volatile elements including arsenic, antimony, and mercury that locally are indicators of precious-metal mineralization. These samples are associated with silicified zones that formed in dolomitic rock beneath the Roberts Mountains thrust fault. These zones have high, moderate, and low resource potential for gold and silver. Two similar areas of silicified and altered dolomite in the southwest part of the study area have moderate-to-low resource potential for gold and silver. An east-west trending zone in the central part of the study area and two areas near its western edge contain anomalous amounts of gold and silver in altered dolomite and limestone associated with major faults and shear zones. These areas have moderate-to-low potential for gold and silver resources. Several mining companies have done extensive exploration for gold and silver and have claim blocks that extend into the study area from the east, west, and south (pl. 1; Benjamin and Johnson, 1986). The areas claimed are
\end{abstract}

included in areas of high and moderate resource potential in this report.

\section{Character and Setting}

The Roberts Wilderness Study Area includes about one-third of the Roberts Mountains in Eureka County, Nevadu. The area is about $30 \mathrm{mi}$ northwest of Eureka and $50 \mathrm{mi}$ south of Carlin (fig. 1). The study area is underlain by a folded and faulted sequence of marine sedimentary rocks of Cambrian through Devonian age (about 570 to 360 million years ago) capped in places by Tertiary (about 65 to 2 million years ago) lava and ash flows and intruded by many Tertiary basalt dikes. Most of the Cambrian through Devonian rocks in the study area are limestone and dolomite. The Roberts Mountains thrust, an important regional structural feature, is present in the southeast part of the wilderness study area.

The Antelope mining district extends into the wilderness study area and is represented by the Kelley mine, a silver, lead, and zinc mine inactive since 1937. Other mines in this district lie outside the wilderness study area. There are extensive mining claims around the study area, and some extend into it.

\section{Identified Resources}

The Kelley mine produced 397 tons of silver, lead, and zinc ore prior to being abandoned in 1937. No resources were identified, at this mine during this study. Anomalous amounts of gold and silver were detected in some rock samples collected elsewhere in the study area, but no identified resources were found.

\section{Mineral Resource Potential}

There are three areas of high mineral resource potential for gold and silver with gradational areas of 


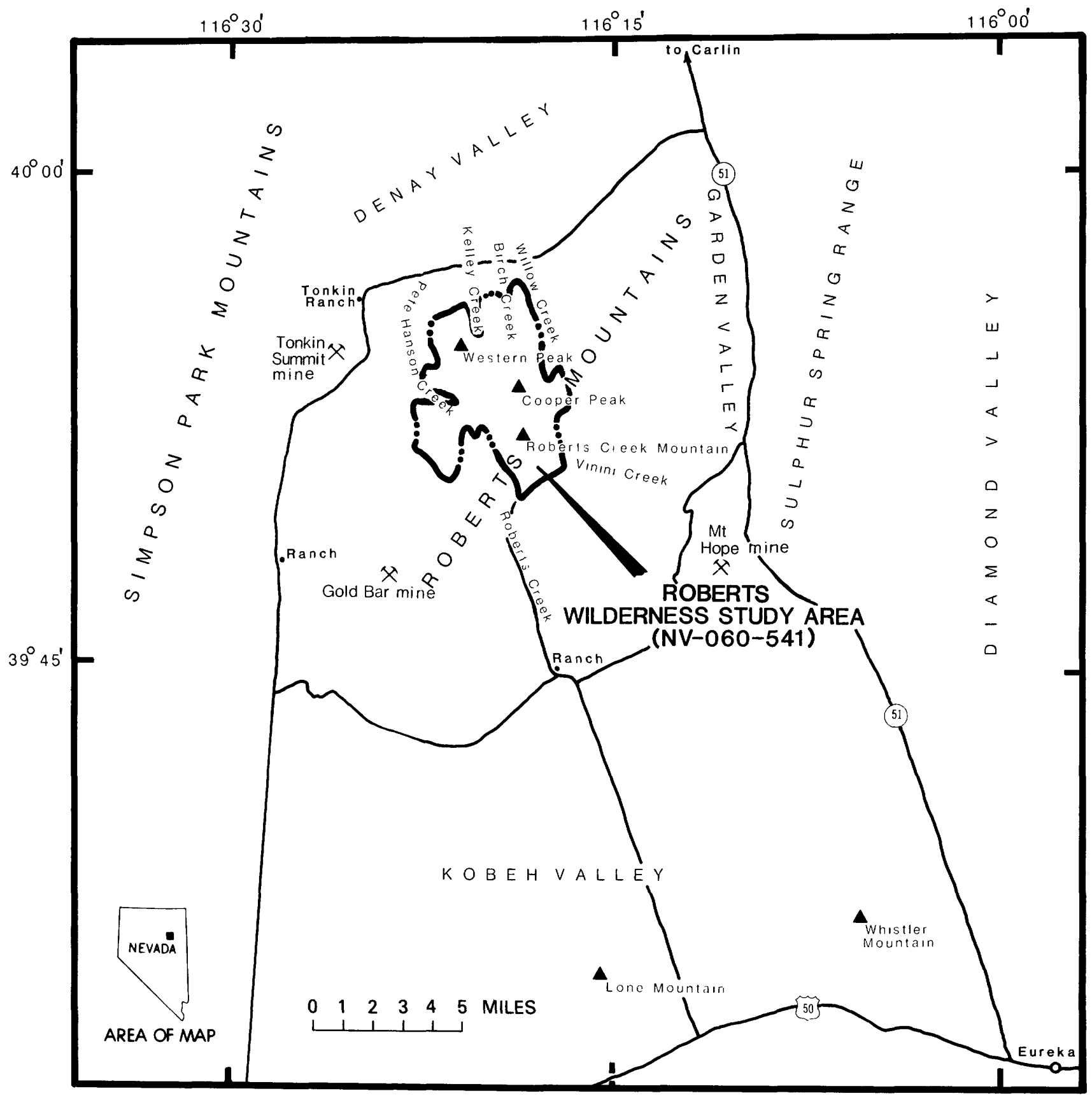

Figure 1. Index map showing location of the Roberts Wilderness Study Area, Eureka County, Nevada. 
moderate and low resource potential in silicified dolomite beneath the Roberts Mountains thrust along part of the eastern edge of the wilderness study area (fig. 2; plate 1). Silica and metals, including gold and silver, are concentrated in irregular replacement bodies in dolomite beneath the silicic rocks of the upper plate of the Roberts Mountains thrust. Silicic shales, cherts, and quartzites of the Vinini Formation in the upper plate of the Roberts Mountains thrust contain anomalous amounts of trace elements and are a possible source for the silica and other elements that mark the sole of the thrust. Silicification took place prior to Tertiary or older high-angle faulting that offsets the siliceous bodies. Silicified and altered dolomite in an area about $21 / 2 \mathrm{mi}$ west of Roberts Creek Mountain has moderate-to-low resource potential for gold and silver (fig. 2; plate 1); and an area along the southwest edge of the study area about $31 / 2 \mathrm{mi}$ west of Roberts Creek Mountain has moderate resource potential for gold and silver in the same geologic setting (fig. 2; plate 1). Gold and silver mineralization in altered dolomite and limestone associated with faulting that is younger than the Roberts Mountains thrust is found in the central part of the wilderness study area and near several large faults in the western part of the study area. These areas have moderate potential for gold and silver resources (fig. 2; plate 1). Silver, lead, and zinc have low mineral resouce potential in the Kelley Creek drainage east of Western Peak (fig. 2; plate 1). The mineralization in this area is in veins in faulted and sheared dolomite that formed by hydrothermal solutions possibly related to the intrusive system of Miocene age (about 25 to 5 million years ago) that underlies the area. No known energy mineral deposits exist in the wilderness study area and there is little or no likelihood of hydrocarbon resources in or beneath the study area.

\section{INTRODUCTION}

\section{Area Description}

The Roberts Wilderness Study Area (NV-060-541) covers 15,090 acres in the north-central part of the Roberts Mountains in central Nevada (fig. 1). The terrain is rugged and the relief is as much as $3,700 \mathrm{ft}$. Elevation ranges from $10,133 \mathrm{ft}$ above sea level at Roberts Creek Mountain to about $6,400 \mathrm{ft}$ above sea level along the north edge of the mountains at the mouth of Birch Creek. The climate is semiarid and the vegetation is typical of the transition climatic zone that supports pinon pine, juniper, and mountain mahogany. Perennial riparian vegetation includes willow, aspen, wild rose, and lush grasses and wildflowers.

The Roberts Mountains are about $30 \mathrm{mi}$ northwest of Eureka, Nev., and $50 \mathrm{mi}$ south of Carlin, Nev. Access to the wilderness study area is by unimproved dirt roads that branch from maintained county roads located along the north edge of the Roberts Mountains and along Roberts Creek in the southern part of these mountains. There are no maintained roads within the wilderness study area, although four-wheel-drive vehicle trails reach high elevations near Roberts Creek Mountain.

\section{Previous and Present Investigations}

The geology of the Roberts Mountains is mapped on a $1: 31,250$ scale map (Murphy and others, 1978) and represents the cumulative work of many geologists and students over a period of about 20 years. A map and summary report on the geology of the Roberts Wilderness Study Area was published by McKee (1986).

The first modern general geologic study of the Roberts Mountains was the classic study of Merriam and Anderson (1942), in which the occurrence of contrasting facies of Paleozoic strata was noted and the concept of telescoping of terrain on regional thrust faults was hypothesized. The name "Roberts Mountains thrust" was applied to the fault on which the telescoping took place. In subsequent years, this fault was recognized at many places in central Nevadu.

The earliest paleontological work in the area was that of Merriam (1940). Some later paleontological studies were done by Johnson (1962a,b, 1966, 1972, and 1977), Berry and Murphy (1975), Murphy (1977), Gregory and others (1977), and Klapper and Johnson (1977). Studies by Winterer and Murphy (1960) established the existence of a reef complex of Silurian and Devonian age in the Roberts Mountains. Papers dealing with the stratigraphy of the region are by Merriam (1940), Murphy and Gronberg (1970), Murphy and Dunham (1977), and Murphy and others (1978). The unique structural features of the Roberts Mountains and a reasonable hypothesis for their development is presented by Winterer (1968). A study by Murphy and others (1984) focuses on the age and internal structure of the Roberts Mountains allochthon.

Vanderburg (1938) reported on mines in the Roberts Mountains. Stream-sediment sample data in Wagoner (1978), and rock-sample data in Mitchell and Quade (1982) include analyses of rocks from the Roberts Mountains. Additional geochemical information is in the U.S. Bureau of Land Management Great Basin Geology Energy Minerul (G.E.M.) Joint Venture, Roberts G.E.M. resources area Technical Report (1983). An aerial radiometric and magnetic survey that includes the Roberts Mountains was prepared for the U.S. Department of Energy by Geodata International (1979), and an aeromagnetic map of the Roberts Mountains was published by Philbin and others (1963), and interpretations of the aeromagnetic survey are in Mabey (1966) and Robinson (1970).

The U.S. Geological Survey carried out field investigations in the study area during the summer of 1984. The work included field checking of existing geologic maps and geochemical sampling. Samples were collected from areas of observed alteration to obtain information about mineral suites and traceelement signatures associated with mineralizing systems.

In 1984, the U.S. Bureau of Mines conducted a literature search of Eureka County, State of Nevada, U.S. Bureau of Mines, and U.S. Bureau of Land Management mining-claim and mineral-lease records. Field studies in 1984 included a search for all mines, 
prospects, and claims within the wilderness study area, and examination and sampling of those found.

\section{APPRAISAL OF IDENTIFIED RESOURCES}

By David A. Benjamin and Fredrick L. Johnson, U.S. Bureau of Mines

\section{Methods and scope of Investigation}

An effort was made to examine, map, and sample claim areas (plate 1). Special attention was given to areas with known metal anomalies or with visible alteration or mineralization.

Four-hundred fifty-eight chip and grab samples were collected in or near the wilderness study area. Four-hundred thirty-six of the samples were analyzed for gold and silver, 14 were analyzed for gold, silver, lead, zinc, and barium, seven were analyzed for gold, silver, and barium, and one sample was analyzed for vanadium. Detailed information on these samples is in Benjamin and Johnson (1986) and in the U.S. Bureau of Mines files at the Western Field Operations Center, Spokane, Wash.

\section{History and Production}

Mining in the area began in the early 1900's with the location of the Kelley claim (fig. 2; plate 1). The Belmont claim, $1.7 \mathrm{mi}$ east of the wilderness study area, was established at about the same time. Both of these mines are in the Antelope mining district. According to Vanderburg (1938), 350 tons of ore was shipped from the Kelley mine in its early stages. The property lay idle from the early 1900's until 1937 when 47 tons of ore was high-graded from the dumps. It was assayed at $0.8 \mathrm{oz} /$ ton silver, 9.6 percent lead, and 39.8 percent zinc. From the condition of the property in 1984 , it appears that no work has been done since the late 1930 's. From the 1930 's until the early 1960 's, only small-scale prospecting, including vanadium exploration in the 1950 's, was done in the Roberts Mountains. Since the discovery in the early 1960's of the Carlin gold mine, a large gold producer about 60 mi north of the Roberts Mountains, extensive preciousmetals exploration has gone on throughout Nevada, including the Roberts Mountains.

In the past five years, major metal deposits have been found in central Nevada not far from the Roberts Mountains. These include a large molybdenum deposit about $7 \mathrm{mi}$ south of the wilderness study area at $\mathrm{Mt}$. Hope (fig. 1) (Tingley and Smith, 1982), a gold deposit near Tonkin Summit $4 \mathrm{mi}$ west of the study area (fig. 1), and a gold deposit called the Gold Bar gold property (fig. 1), (Skillings' Mining Review, 1984) about $5 \mathrm{mi}$ south of the study area.

During the late 1970 's and early 1980 's, exploration for barite was widespread in the Roberts Mountains. Three barite mines were developed within a few miles of the wilderness study area: 10,000 tons of barite was mined from the Bat and Bar claims near the northeast edge of the study area and several hundred tons were mined from the Firecracker claim group near the southwest edge of the study area. As of 1985 , there was no activity at these mines.

\section{Mineral deposits}

The Kelley mine produced 397 tons of silver, lead, and zinc ore prior to 1937. No production has been reported since and no resources were identified at the mine during this study. Fourteen chip samples were taken from the mine. Samples from ore zones average 0.02 parts per million (ppm) gold, $8.02 \mathrm{ppm}$ silver, 2.13 percent lead, and 3.85 percent zinc.

Two-hundred thirty-one random chip or grab samples were collected at sites in or near active goldsilver claim blocks (these sites are located in the areas of high, moderate, and low mineral resource potential shown on fig. 2 and pl. 1). Eighty-one of these samples contained no detectable gold or silver, 50 had gold above the detection limit $(0.007 \mathrm{ppm}), 71$ had silver above the detection limit $(0.3 \mathrm{ppm})$, and 29 had both gold and silver above the detection limit. Low-grade precious-metal resources may be present at these sites, but many more samples must be collected (including drill samples) before any mineral resourees can be delineated.

ASSESSMENT OF MINERAL RESOURCE POTENTIAL By Edwin H. McKee, Harlan N. Barton, and David A. Ponce, U.S. Geological Survey

\section{Geology}

The rocks in the Roberts Mountains range in age from Cambrian to Holocene. The wilderness study area occupies a part of these mountains and is comprised mostly of lower Paleozoic strata and some Tertiary volcanic rocks, primarily basalt dikes and lava flows.

The Paleozoic rocks consist of two contrasting sedimentary assemblages deposited in different marine environments. One assembluge, consisting mostly of carbonate rocks, was deposited on a broad continental shelf. Variations in these carbonate strata are related to the distribution of reefs, shallow subtidal regions, and deeper basins on the continental shelf. A complex, intertonguing relationship between coarse-grained algal, coral-rich limestone-dolomite (ancient reef), and thin-bedded, finely laminated limey mudstones with interbeds rich in reef debris (shelf-basin deposits) clearly define the continental shelf with its great variety of subenvironments. The other assemblage consists of the following lithologies: dark graptolitebearing shale; bedded chert; thin, clean sandstone beds; thin, dark fine-grained limestone; a small amount of bedded barite; and massive, lenticular volcanic breccias. These rocks were deposited in deep water, probably many miles from the edge of the continental shelf and the continental slope. The two rock assemblages, representing different environments that must have once been many miles apart, have been brought together in the Roberts Mountains by the Roberts Mountains thrust, which was active in central Nevada in Late Devonian and Mississippian time. At a few places in the Roberts Mountains (but not within the wilderness study area) and the surrounding region, 
there are coarse conglomeratic deposits of Pennsylvanian and Permian age that were derived from the upper plate (deep-water assemblage) of the Roberts Mountains thrust. Presumably, these rocks eroded from the thrust plate and define the youngest age of thrusting.

Tertiary rocks within the wilderness study area are mostly volcanic or hypabyssal types ranging in composition from rhyolite to basalt. Rhyolitic and dacitic rocks occur as isolated outliers of regionally extensive ash-flow sheets, air-fall tuffs, or reworked tuffs that contain a large proportion of nonvolcanic detritus. Small lava flows are present as well. Other silicic igneous rocks are largely or entirely intrusive, forming small stocks, plugs, or domes. These intrusive bodies, now deeply eroded, may have once extended to the surface and been the source for some of the ash or lava that occurs in the region. Radiometric ages of a number of the rhyolitic or dacitic rocks in the Roberts Mountains indicate that most are of Oligocene age. Basalts and basaltic andesites are the most abundant igneous rock type in the wilderness study area. The Roberts Mountains are the site of one of the bestexposed basaltic dike swarms in the western United States. These dikes trend north-northwest across the western and west-central part of the mountains; many individual dikes can be traced for a mile or more. From the air, this dike swarm is especially well expressed, giving the landscape a strongly striped appearance. Some basaltic lava flows also occur in the area; radiometric dating indicates that these basalts are middle Miocene in age (McKee and Noble, 1986).

\section{Geochemical Studies}

The reconnaissance geochemical study is based on analysis and evaluation of rock samples and heavymineral concentrates of stream-sediment samples.

Rock samples collected from silicified rocks at sites in the Roberts Mountains were analyzed for 31 elements by a six-step semiquantitative emissionspectrographic method (Grimes and Marranzino, 1968). Samples were also analyzed for arsenic by colorimetric methods, for antimony and gold by atomic absorption spectrophotometry, and mercury by an instrumental technique. The analytical data are in Barton and others (1986).

Samples of heavy-mineral concentrates provide information about the chemistry of a limited number of minerals in rock material eroded from the drainage basin upstream from each sample site. The selective concentration of minerals permits determination of some elements that are not easily detected in streamsediment samples. Results of the analysis of heavymineral concentrates by the semiquantitative spectrographic method are reported in Day and Barton (1986). These samples contain material from rock units of drainage basins up to one $\mathrm{mi}^{2}$.

Areas or drainages with anomalous concentrations of metallic or metal-related elements were identified by inspection of the data for enrichment relative to crustal abundance. Most often these anomalies reflect known mining activity, but in some instances they indicate areas of undisclosed or previously unrecognized mineralization.
Geochemical anomalies in silver, cadmium, lead, zinc, and barium were found in concentrates from stream-sediment samples from Kelley Creek. Anomalies from sumples collected downstreum from the Kelley mine probubly reflect this mine; anomalies from the eastern tributary to Kelley Creek indicate eroded rock contuining these metals. This elementul suite is typical of hydrothermal silver, lead, and zinc deposits hosted by carbonate rocks.

Anomalous amounts of gold, silver, ursenic, antimony, and mercury are found in sumples of silicified dolomite collected at many places in the Roberts Mountains. This suite of precious and volutile elements in close association with silicified rocks (jasperoid) is typical of disseminuted, fine-grained gold deposits.

\section{Geophysical Studies}

\section{Gravity data}

A regional Bouguer gravity map that includes the wilderness study area shows a distinct gravity high over the Roberts Mountuins (Erwin and Bittleston, 1977). The amplitude of the high is about 5 to $8 \mathrm{mGal}$ and reflects the relatively dense Paleozoic strutified rocks and Tertiary basalts exposed in the Roberts Mountains. A steep gravity gradient of about 7 to 10 $\mathrm{mGal} / \mathrm{mi}$ is coincident with the northwest front of the Roberts Mountains and indicates a near-vertical boundary with Denay Valley. In generul, gravity lows adjacent to the Roberts Mountains reflect an increase in thickness of low-density sediments und volcanic rocks in surrounding valleys. Southeast of the study area, a circular gravity low of about $2 \mathrm{mGal}$ occurs over Mount Hope. This low probubly reflects lowerdensity rhyolite porphyry intruding the Paleozoic rocks at Mount Hope.

\section{Aeromagnetic data}

A total-intensity aeromagnetic survey was flown in 1960 and 1961 at a constant barometric flight elevation of $9,000 \mathrm{ft}$ and with a north-south flight-line spacing of $1 \mathrm{mi}$ (Philbin and others, 1963). The most prominent magnetic feature in the wilderness study area is a linear magnetic high trending northnorthwest that bisects the Roberts Mountains. The anomaly has a maximum amplitude of over 500 gammas and overlies the basalt dike swarm exposed in the northern part of the Roberts Mountains. Threedimensional modeling of the magnetic anomaly overlying the basalt dikes suggests that the causative body is about $2 \mathrm{mi}$ wide and extends to a depth of about $8 \mathrm{mi}$ (Robinson, 1970). This magnetic unomaly is the southern part of a much larger linear magnetic feature (Mabey, 1966).

The dimensions of the dike swarm beneath the Roberts Mountains inferred from geologic mapping and aeromagnetic and gravity data may provide information relevant to mineral deposits. An igneous system as large as the one beneuth the Roberts Mountains may have been directly or indirectly responsible for some of the mineralization in the wilderness study area. Hydrothermal mineralization 


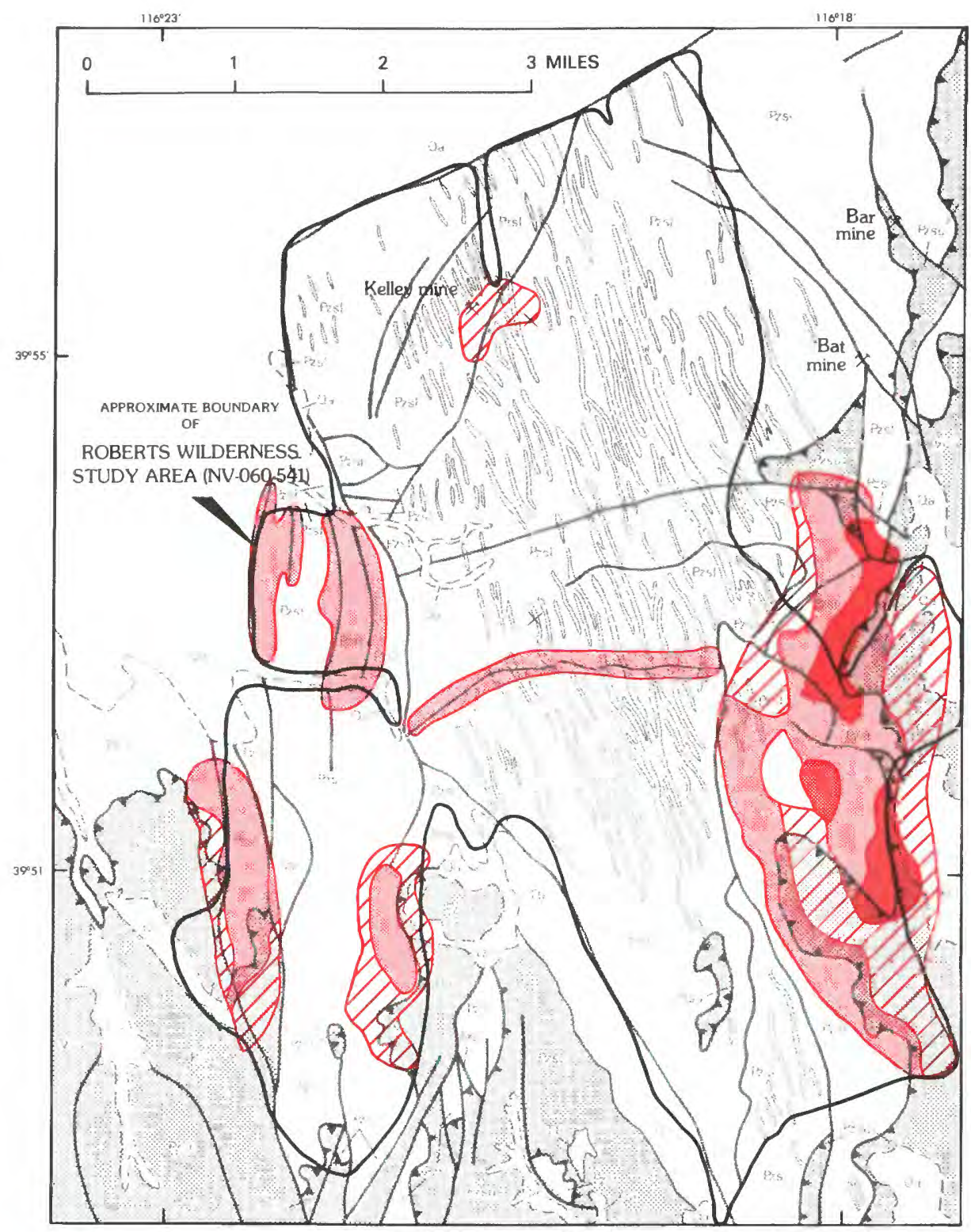

EXPLANATION

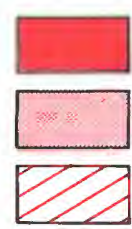

Area with high mineral resource potential

Area with moderate mineral resource potential

Area with low mineral resource potential. Data indicate resource potential, but do not establish activity of resourceforming processes

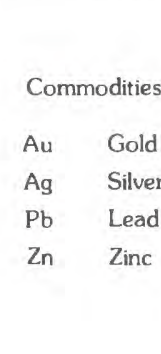

$\begin{array}{ll}x & \text { Mine } \\ \times \quad \text { Prospect }\end{array}$

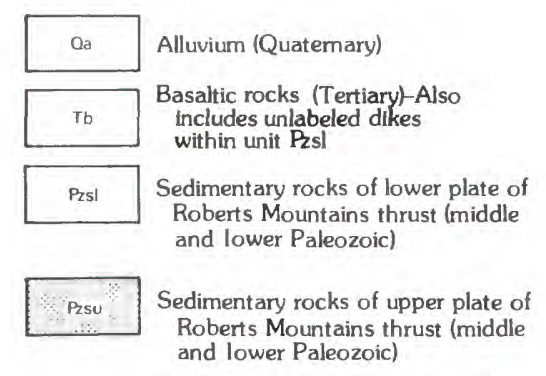

Contact-Dashed where inferred

High and low-angle faults

Roberts Mountains thrust

Figure 2. Map showing mineral resource potential of the Roberts Wilderness Study Area. 
localized along faults cut by dikes in the central part of the wilderness study area could be related to hydrothermal solutions from the magma system, or indirectly caused by heating and mobilization of fluids in the rocks due to the emplacement of the dike swarm.

\section{Mineralization}

Metallic and nonmetallic elements present in anomalous amounts in the heavy-mineral concentrate of stream-sediment and rock samples indicate two types of mineralization exist in the wilderness study area. Additional types of mineralization, such as barium in bedded barite, occur within a few miles of the study area.

Gold and silver in silicified dolomite beneath the Roberts Mountains thrust offers the greatest mineral resource potential in the wilderness study area. The silicified dolomite forms irregular bodies as much as $100 \mathrm{ft}$ thick and covering as much as one-half $\mathrm{mi}^{2}$. These bodies consist of massive to lattice-like, highly iron-stained silica, that locally contain anomalous amounts of arsenic, antimony, and mercury, and trace amounts of gold and silver. Dark silicic shale, chert, and quartzite of the Vinini Formation of the upper plate of the Roberts Mountains thrust contain abundant trace elements and metals, and are a possible source of the silica and trace elements found in the sole of the thrust. Mobilization of these elements was on a regional scale at moderately high temperatures. Silicification and mineralization are older than many of the high-angle faults in the region that cut the Roberts Mountains thrust and the silicified dolomite.

A second type of mineralization that occurs in the wilderness study area is gold, silver, lead, and zinc-bearing calcite and quartz veins that formed by hydrothermal solutions in dolomite. Faults and shear zones in the dolomite probably acted as conduits for the hydrothermal solutions and tend to be sites of mineralization. Geochemical anomalies in these metals, as well as barium and cadmium, are found in the Kelley Creek drainage. The Kelley mine, a silver, zinc, and lead mine in Kelley Creek, is in dolomite. The source of the hydrothermal solutions is not known.

\section{CONCLUSIONS}

Information from geologic studies, geochemical sampling, and examination of mines, prospects, and mineralized areas indicates that there are two types of mineralization in the Roberts Wilderness Study Area. There are additional types of mineralization (bedded barite and molybdenum porphyry) known to be present in surrounding areas within a few miles of the study area, but there is no indication that they exist in the study area.

The most promising type of mineralization in the wilderness study area is gold and silver in silicified dolomite. Anomalous amounts of gold and silver are found in selected samples of silicified and iron-stained dolomite that forms irregular bodies beneath the Roberts Mountain thrust at many places in the Roberts Mountains. A suite of volatile elements (arsenic, antimony, and mercury), commonly associated with precious-metal concentrations, is present in anomalous amounts in these silicified rocks as well. The silicified zones are clearly located on the sole of the Roberts Mountains thrust. Other geologic features do not have an apparent relationship to the silicification. Rocks in the upper plate of the Roberts Mountains thrust, and hence everywhere above the silicified zones, are silicic sedimentary types rich in trace elements. These rocks are a possible source of the trace elements, including gold and silver, that are enriched in the silicified zones. Heat necessary to mobilize the elements was of regional extent as the siliceous bodies are found at widely separated localities in the Roberts Mountuins. The silicified zones are cut by Tertiary and older faults. Areas along the east side of the study area east of Roberts Creek Mountain and Cooper Peak have high, moderate, and low resource potential, with a certainty level of $\mathrm{C}$ for gold and silver in bodies of silicified dolomite (fig. 2; pl. 1). See Appendix 1 and figure 3 for the definition of levels of mineral resource potential and certainty of assessment. Silicified and altered dolomite in an area about $21 / 2 \mathrm{mi}$ west of Roberts Creek Mountain has moderate-to-low resource potential, certainty level B for gold and silver (fig. 2; pl. 1). An area along the southwest edge of the wilderness study area about $31 / 2 \mathrm{mi}$ west of Roberts Creek Mountain has a moderate resource potential (certainty level B) for gold and silver (fig. 2; pl. 1).

The second type of mineralization is hydrothermal, carbonate-hosted silver, lead, and zinc vein deposits that form along faults and shear zones. The Kelley mine, on the west fork of Kelley Creek, is a good example of this type of deposit. The area east of Western Peak, including the drainage of both forks of Kelley Creek (fig. 2; pl. 1), has low resource potential (certainty level C) for silver, lead, and zinc in veins or stockworks in dolomite. Gold and silver mineralization in altered dolomite and limestone associated with faulting younger than the Roberts Mountains thrust and older than Tertiary basin and range faults is found in the central part of the wilderness study area and near severul large faults in the western part of the study area. These areas have moderate potential for gold and silver resources with a B certainty level (fig. 2; pl. 1).

\section{REFERENCES CITED}

Barton, H. N., Day, G. W., Detra, D. E., and O'Leary, R. M., 1986, Analytical results and sample locality map of rock samples from the Roberts Mountains, Eureka County, Nevada: U.S. Geological Survey Open-File Report 86-224.

Benjamin, D. A., and Johnson, F.L., 1986, Mineral resources of the Roberts Wilderness Study Area, Eureka County, Nevada: U.S. Bureau of Mines Open-File Report, MLA 24-86.

Berry, W. B. N., and M. A. Murphy, 1975, Silurian and Devonian graptolites of central Nevada: University of California Publications in Geological Sciences; v. 110, 109 p.

Day, G. W., and Barton, H. N., 1986, Analytical results and sample locality map of heavy-mineralconcentrate samples from the Roberts Wilderness Study Area (NV-060-541), Eureka County, Nevada: U.S. Geological Survey Open-File Report 
86-223.

Erwin, J. W., and Bittleston, E. W., 1979, Bouguer gravity map of Nevada, Millett sheet: Nevada Bureau of Mines and Geology Map 53, scale $1: 250,000,1$ sheet.

Geodata International Inc., 1979, Aerial radiometric and magnetic survey, Millet $t$ national topographic map, Nevada: Prepared for the U.S. Depart ment of Energy, Grand Junction, Colorado, GJBX154(79), $62 \mathrm{p}$.

Gregory, J. T., Morgan, T. G., and Reed, J. W., 1977, Devonian fishes in central Nevada: in Murphy, M.A., Berry, W.B.N., and Sandberg, C.A. eds. Western North America: Devonian, University of California, Riverside, Campus Museum, Contribution 4, p. 112-121.

Grimes, D.J., and Marranzino, A.P., 1968, Directcurrent arc and alternating-current spark emission spectrographic field methods for the semiquantitative analysis of geologic materials: U.S. Geological Survey Circular 591, 6 p.

Johnson, J.G., 1962, Brachiopod faunas of the Nevada Formation (Devonian) in central Nevada: Journal of Paleontology, v. 36, no. 1, p. 165-169.

1962, Lower Devonian-Middle Devonian boundary in central Nevada: American Assoc. Petroleum Geologists Bulletin, v. 46, no. 4, p. 542-546. 1966, Middle Devonian brachiopods from the Roberts Mountains, central Nevada: Paleontology, v. 9, pt. 1, p. 152-181.

1972, The Antistrix brachiopod faunule from the Middle Devonian of central Nevada: Journal of Paleontology v. 46, no. 1, p. 120-124.

1977, Lower and Middle Devonian faunal intervals in central Nevada Based on Brachiopods. in Murphy, M.A., Berry, W.B.N., and Sandberg, C.A., eds. Western North America: Devonian, University of California, Riverside Campus Museum, Contribution 4, p. 16-32.

Klapper, Gilbert and Johnson, D.B., 1977, Lower and Middle Devonian conodont sequence in central Nevada: in Murphy, M.A., Berry, W.B.N., and Sandberg, C.A. eds., Western North America: Devonian, University of Califoria, Riverside Campus Museum, Contribution 4, p. 33-55.

Mabey, D.R., 1966, Regional gravity and magnetic anomalies in part of Eureka County, Nevada, in Mining Geophysics, v. 1, Case Histories: Society of Exploration Geophysicists, p. 77-83.

McKee, E.H., 1986, Geologic map of the Roberts Wilderness Study Area, Eureka County, Nevada: U.S. Geological Survey Miscellaneous Field Studies Map MF-1844, Scale $1: 48,000$.

McKee, E. H., and Noble, 1986, Tectonic and magmatic development of the Great Basin of western United States during late Cenozoic time: Modern Geology, v. 10, p 39-49.

Merriam, C.W., 1940, Devonian stratigraphy and paleontology of the Roberts Mountains region, Nevada: Geological Society of America, Special Paper 25, 114 p.

Merriam, C.W., and Anderson, C.A., 1942, Reconnaissance survey of the Roberts Mountains, Nevada: Geological Society of America Bulletin, v. 53, no. 11 , p. 1675-1728.

Mitchell, T.P., and Quade, J.G., 1982, National
Uranium Resource Evaluation, Millett quadrangle, Nevada: Bendix Field Engineering Corporation, Grand Junction, Colorado, PGJ/F-138(82), 26 p.

Murphy, M.A., 1977, Middle Devonian rocks of central Nevada: in Murphy, M. A., Berry, W. B. N, and Sandberg, C. A., Western North America: Devonian, Univ. of California, Riverside Campus Museum, Contribution 4, p 190-200.

Murphy, M.A., and Gronberg, E.C. 1970, Stratigraphy and correlation of the Lower Nevada Group (Devonian) North and West of Eureka, Nevada: Geological Society of America Bulletin, v. 81, no. p. 127-136.

Murphy, M. A., and Dunham, John, 1977, Middle and Upper(?) Devonian Stromatoporoid boundstones and associated facies, Devils Gate Limestone, Eureka County, Nevada: in Murphy, M. A., Berry, W.B.N., and Sandberg, C. $\bar{A} .$, eds. Western North America: Devonian, University of California, Riverside Campus Museum, Contribution 4, p. 200-204.

Murphy, M.A., McKee, E.H., Winterer, E.L., Matti, J.C., and Dunham, J.B., 1978, Preliminary geologic map of the Roberts Creek Mountain quadrangle, Nevada: U.S. Geological Survey Open-File Map 78-316, scale 1:31,250.

Murphy, M.A., Power, J.D., and Johnson, J.G., 1984, Evidence for Late Devonian movement within the Roberts Mountains allochthon, Roberts Mountains, Nevada: Geology, v. 12, p. 20-23.

Philbin, P.W., Meuschke, J.L., and McCaslin, W.E., 1963, Aeromagnetic map of the Roberts Mountains area, central Nevada: U.S. Geological Survey Open-File Report, 63-107, scale 1:125,000.

Robinson, E.S., 1970, Relations between geologic structure and aeromagnetic anomalies in central Nevada: Geological Society of America Bulletin, v. 81, no. 7, p. 2045-2060.

Skillings' Mining Review, 1984, Atlas Corp. announces discovery of Gold Bar deposit in Nevada, v. 73, no. 37, p. 8.

Tingley, J.V., and Smith, P.L., 1982, Mineral inventory of Eureka-Shoshone resource area: Nevada Bureau of Mines and Geology Open-File Report 82-10, 20 p.

U.S. Bureau of Land Management Great Basin G.E.M. Joint Venture, 1983, Roberts G.E.M. resources area (GRA No. NV-08): Technical Report (WSA NV 060-541), (contract YA-553-RFP2-1054), 33 p. Available through the U.S. Bureau of Land Management Denver Service Center, Bldg. 50, Denver Federal Center, Denver, CO.

Vanderburg, W.O., 1938, Reconnaissance of mining districts in Eureka County, Nevada: U.S. Bureau of Mines Information Circular 7022, $66 \mathrm{p}$.

Wagoner, J.L., 1978, Hydrogeochemical and stream sediment reconnaissance basic data report for Millett NTMS quadrangles, Nev. Lawrence Livermore Lab, University of California, GJBX39(79), 22 p.

Winterer, E.L., and Murphy, M.A., 1960, Silurian reef complex and associated facies, central Nevada: Journal of Geology, v. 68, no. 2, p. 117-169.

Winterer, E.L., 1968, Tectonic erosion in the Roberts Mount ains, Nevada: Journal of Geology, v. 76, p. 347-357. 
APPENDIX 1. Definition of levels of mineral resource potential and certainty of assessment

Mineral resource potential is defined as the likelihood of the presence of mineral resources in a defined area; it is not a measure of the amount of resources or their profitability.

Mineral resources are concentrations of naturally occurring solid, liguid, or gaseous materials in such form and amount that economic extraction of a commodity from the concentration is currently or potentially feasible.

Low mineral resource potential is assigned to areas where geologic, geochemical, and geophysical characteristics indicate a geologic environment where the existence of resources is unlikely. This level of potential embraces areas of dispersed mineralized rock as well as areas having few or no indications of mineralization. Assignment of low potential requires specific positive knowledge; it is not used as a catchall for areas where adequate data are lacking.

Moderate mineral resource potential is assigned to areas where geologic, geochemical, and geophysical characteristics indicate a geologic environment favorable for resource occurrence, where interpretations of data indicate a reasonable chance for resource accumulation, and where an application of genetic and (or) occurrence models indicates favorable ground.

High mineral resource potential is assigned to areas where geologic, geochemical, and geophysical characteristics indicate a geologic environment favorable for resources, where interpretations of data indicate a high likelihood for resource accumulation, where data support occurrence and (or) genetic models indicating presence of resources, and where evidence indicates that mineral concentration has taken place. Assignment of high resource potential requires positive knowledge that resource-forming processes have been active in at least part of the area; it does not require that occurrences or deposits be identified.

Unknown mineral resource potential is assigned to areas where the level of knowledge is so inadequate that classification of the area as high, moderate, or low would be misleading. The phrase "no mineral resource potential" applies only to a specific resource type in a well-defined area. This phrase is not used if there is the slightest possibility of resource occurrence; it is not appropriate as the summary rating for any area.

Expression of the certainty of the mineral resource assessment incorporates a consideration of (1) the adequacy of the geologic, geochemical, geophysical, and resource data base available at the time of the assessment, (2) the adequacy of the occurrence or the genetic model used as the basis for a specific evaluation, and (3) an evaluation of the likelihood that the expected mineral endowment of the area is, or could be, econo mically extractable.

Levels of certainty of assessment are denoted by letters, A-D (fig. 3).

A. The available data are not adequate to determine the level of mineral resource potential. Level $\mathrm{A}$ is used with an assignment of unknown mineral resource potential.

B. The available data are adequate to suggest the geologic environment and the level of mineral resource potential, but either evidence is insufficient to establish precisely the likelihood of resource occurrence, or occurrence and (or) genetic models are not known well enough for predictive resource assessinent.

C. The available data give a good indication of the geologic environment and the level of mineral resource potential, but additional evidence is needed to establish precisely the likelihood of resource occurrence, the activity of resource-forming processes, or available occurrence and (or) genetic models are minimal for predictive applications.

D. The available data clearly define the geologic environment and the level of mineral resource potential, and indicate the activity of resourceforming processes. Key evidence to interpret the presence or absence of specified types of resources is available, and occurrence and (or) genetic models are adequate for predictive resource assessment.

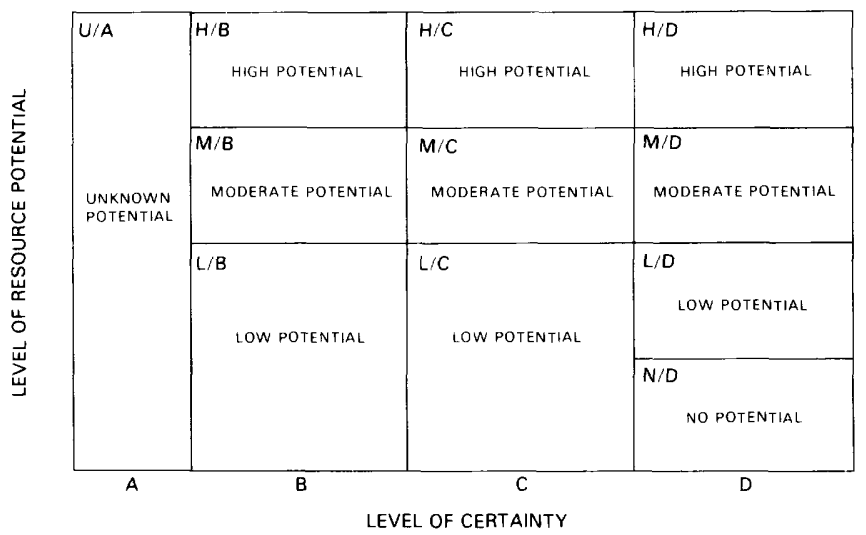

Figure 3. Major elements of mineral resource potential/certainty classification. 
Table 1. Sample description and analyses of chip samples from Kelley mine

\begin{tabular}{|c|c|c|c|c|c|c|}
\hline $\begin{array}{l}\text { length } \\
\text { ( } \mathrm{ft})\end{array}$ & Description & $\begin{array}{l}\text { Gold } \\
\text { (ppm) }\end{array}$ & $\begin{array}{l}\text { Silver } \\
(\mathrm{ppm})\end{array}$ & $\begin{array}{c}\text { Lead } \\
\text { (percent) }\end{array}$ & $\begin{array}{c}\text { Zinc } \\
\text { (percent) }\end{array}$ & $\begin{array}{c}\mathrm{BaSO}_{4} \\
\text { (percent) }\end{array}$ \\
\hline 4.4 & $\begin{array}{l}\text { Shear zone: partly oxidized broken carbonate rock, } \\
\text { galena, barite crystals }\end{array}$ & 0.017 & 22.62 & 6.7 & 10.8 & 18.5 \\
\hline 3.0 & $\begin{array}{l}\text { Shear zone: partly oxidized, galena, sphalerite, } \\
\text { barite- }\end{array}$ & $<.007$ & 3.16 & 1.04 & 4.2 & 19.1 \\
\hline 3.0 & $\begin{array}{l}\text { Shear zone: mostly black oxide in a white quartz } \\
\text { matrix- }\end{array}$ & $<.007$ & .43 & .055 & .242 & .09 \\
\hline $\begin{array}{l}1.5 \\
2.3\end{array}$ & Shear zone: brecciated carbonate rock & $<.005$ & $\begin{array}{c}13.89 \\
<.3\end{array}$ & $\begin{array}{l}2.86 \\
.016\end{array}$ & $\begin{array}{l}4.0 \\
.018\end{array}$ & $\begin{array}{l}6.5 \\
.03\end{array}$ \\
\hline $\begin{array}{l}2.0 \\
3.0\end{array}$ & Hanging wall; brecclated carbonate rock- & $\begin{array}{l}<.007 \\
<.007\end{array}$ & $\begin{array}{r}.87 \\
1.22\end{array}$ & $\begin{array}{l}.187 \\
.135\end{array}$ & $\stackrel{.96}{1.4}$ & $<.02$ \\
\hline 4.0 & Footwall: carbonate rock with minor calcite stringers & $<.007$ & 3.9 & .88 & 2.04 & 1.68 \\
\hline $\begin{array}{l}3.0 \\
4.0\end{array}$ & $\begin{array}{l}\text { Footwall: silicified carbonate- } \\
\text { Footwall: fractured carbonate rock, minor calcite }\end{array}$ & $\begin{array}{l}<.007 \\
<.007\end{array}$ & $<.39$ & $\begin{array}{l}.042 \\
.004\end{array}$ & $\begin{array}{l}.057 \\
.004\end{array}$ & $<.08$ \\
\hline & stringers & & & & & \\
\hline 2.0 & Basalt dike: black, fine-grained, looks fresh & $<.007$ & $<.3$ & .012 & .079 & .09 \\
\hline 2.0 & $\begin{array}{l}\text { Basalt-carbonate rock contact: fractured, minor calcite } \\
\text { velning }\end{array}$ & .012 & $<.3$ & .013 & .1 & .21 \\
\hline 1.0 & $\begin{array}{l}\text { Basalt-carbonate rock contact: brecciated carbonate rock, } \\
\text { strong 1ron oxide boxwork texture, fine-grained } \\
\text { galena and sphalerite- }\end{array}$ & .046 & 16.54 & 1.33 & 9.2 & $<.02$ \\
\hline 1.0 & $\begin{array}{l}\text { Basalt-carbonate rock contact: fractured, silicified } \\
\text { carbonate rock }\end{array}$ & $<.007$ & $<.3$ & .007 & .004 & $<.02$ \\
\hline
\end{tabular}

